\title{
POESIA E HISTÓRIA: CONSIDERAÇÕES SOBRE FERNANDO PESSOA E MANUEL ALEGRE
}

\author{
Marcelo Ferraz de Paula ${ }^{1}$
}

\begin{abstract}
Resumo: Este artigo propõe algumas reflexões sobre as intrincadas relações entre poesia e história. Para tanto, realiza uma leitura crítica do poema "Os jogadores de xadrez", de Fernando Pessoa - mais precisamente de seu heterônimo Ricardo Reis -, e do poema "Lição do arquitecto Manuel da Maia", de Manuel Alegre. Os dois textos colocam em questão a função e os limites da poesia diante das catástrofes históricas: o primeiro por meio da referência a uma guerra genérica e o segundo através da destruição deixada pelo terremoto que assolou a cidade de Lisboa em 1755. O objetivo é aproximar a postura de alheamento, à primeira vista hostil ao plano da História, presente no poema de Pessoa, da tarefa benjaminiana que assume o poema de Alegre, centrado na recuperação ativa das ruínas do passado como forma de reinvenção do presente.
\end{abstract}

Palavras-chave: Poesia Portuguesa; Fernando Pessoa; Manuel Alegre; História

\begin{abstract}
This article develops some reflections about the intricate relationships between poetry and history. In order to do so, we performs a critical reading of the poem "Os jogadores de xadrez", by Fernando Pessoa - more precisely from his heteronym Ricardo Reis -, and the poem "Lição do arquitecto Manuel da Maia", by Manuel Alegre. Both texts explores the function and limits of poetry in the face of historical catastrophes: the first through reference to a generic war and the second through the destruction caused by the earthquake that struck the city of Lisbon in 1755. The aim is to think about the attitude of alienation, at first sight hostile to the plane of History, present in Pessoa's poem, and the Benjaminian task that assumes the poem of Alegre, centered on the active recovery of the ruins of the past as a form of reinvention of the present.
\end{abstract}

Keywords: Portuguese poetry; Fernando Pessoa; Manuel Alegre; History.

Neste artigo pretendemos elaborar algumas considerações sobre a relação entre poesia e história por meio da análise comparativa de dois poemas do repertório da lírica moderna portuguesa. Um deles é o poema comumente chamado de "Os jogadores de xadrez" seguindo o título provavelmente provisório com o qual ficou registrado nos manuscritos de

\footnotetext{
${ }^{1}$ Professor da Universidade Federal de Goiás e membro do quadro permanente do Programa de Pósgraduação em Letras e Linguística (UFG). Contato: marcelo2867@gmail.com
} 
Pessoa (aliás, um dos raríssimos poemas do heterônimo Ricardo Reis intitulados) -, o outro, o poema "Lição do arquitecto Manuel da Maia", de Manuel Alegre. Algumas décadas afastam a produção destes dois escritores, que escreveram em contextos muito diversos da história portuguesa e mundial, em um horizonte ideológico e estético também bastante distinto. Entretanto, as catástrofes que abalaram intensamente o século XX - esta Era de Extremos, como bem o definiu Eric Hobsbawm (2010) - recebem nestes dois poemas um tratamento literário que justifica uma aproximação crítica entre eles. O conceito de história que acionamos no decorrer da leitura é principalmente apoiado numa perspectiva benjaminiana, pensando, portanto, a história como um contínuo acumular de ruínas, e a tarefa do historiador-catadortrapeiro, análoga a do poeta moderno: por meio do ruminar dos detritos do passado erigir um discurso de intervenção sobre o presente. Afirma o autor, em célebre passagem de suas teses sobre o conceito da história: "O dom de despertar no passado as centelhas da esperança é privilégio exclusivo do historiador convencido de que também os mortos não estarão em segurança se o inimigo vencer. E esse inimigo não tem cessado de vencer” (BENJAMIN, 1996, p. 224-225).

Conforme se evidenciará no decorrer da análise, a aproximação aqui empreendida será estruturada a partir do exame da relação entre arte e catástrofe tensionada nos poemas e no sentido alegórico que assumem, explorando a forma "exemplar" das narrativas tradicionais, tangenciando o gênero parábola. Assim, verificamos que os poemas em questão adotam posições político-filosóficas frontalmente opostas no que concerne ao papel da arte na representação da violência extrema, contudo, num exercício analítico mais acurado, revelam-se pontos de contato, ou mesmo de convergência, dos mais interessantes e significativos, capazes de evidenciar a sedimentação dos impasses históricos na autonomia - ora almejada ora combatida, mas sempre relativa - do discurso poético.

\section{Os jogadores de xadrez}

É compreensível encontrarmos na recepção da obra de Fernando Pessoa, em toda a pluralidade de leituras e correntes críticas e filosóficas que por ela se interessaram, uma caracterização recorrente: a de que a sua poesia é voltada quase que exclusivamente para a 
formulação de uma subjetividade radicalmente labiríntica, orbitando em torno de um entrave existencial, ou mesmo ontológico, em detrimento da matéria social. Nos enigmas e mistérios que frequentam a sua poesia, seriam raros os textos que estabelecem um enfrentamento mais nítido da realidade social, seja ela europeia, portuguesa ou mundial. Como observa Joana Matos Frias, “o poetodrama pessoano pode ser acusado, como muitos outros da sua época (em particular no caso português), de um certo alheamento quase autista face à realidade nãoartística [...]" (FRIAS, 2014, 80).

Num outro diapasão, também não são escassos os estudos que se concentram nas posições intelectuais e nas escolhas políticas de Pessoa, para além (ou aquém) de sua poética. Tais investigações situam o perfil intelectual de Pessoa, em geral, como politicamente indiferente, quando não conservador ou mesmo francamente reacionário ${ }^{2}$. Seus múltiplos heterônimos (e não falamos apenas dos quatro mais conhecidos) têm, de fato, em sua miscelânea de particularidades formais e biográficas, ao menos em comum o traço dessa visão de mundo, digamos, cética, anti-revolucionária, sempre à margem das pautas progressistas de seu tempo.

Ricardo Reis configuraria o ápice desse sentimento "apolítico". Os mínimos detalhes de seu perfil biográfico e de sua poética estão alicerçados numa posição marcada pela indiferença aos impasses sociais, numa posição de "desapego total àquilo que é terreno" (VASCONCELLOS, 2012, p. 111), alheamento intransigente às palavras de ordem da vida pública e uma ataraxia militante (SALGADO; ATHAYDE, 2013, p. 74). Tal postura integra o núcleo central de sua obra e consagrou este heterônimo como uma espécie de arquétipo do sujeito alienado, paradoxalmente lançado num contexto histórico em polvorosa, como exploraria magistralmente José Saramago (1984) em um dos seus mais importantes romances. Daí ser ele o "mais emblematicamente anestesiado" dos heterônimos pessoanos, sendo "quase

\footnotetext{
${ }^{2}$ Fiquemos, à guisa de exemplificação, com a sintética definição das orientações políticas de Pessoa realizada por José Barreto: "Do radicalismo republicano dos 18-20 anos [Fernando Pessoa] evoluiu para um pensamento conservador e elitista de verve antidemocrática, sem perder a sua singularidade e independência crítica. Defendeu causas perdidas e simpatizou com modelos políticos anacrónicos - como o absolutismo esclarecido de Frederico o Grande da Prússia, de quem elogiava a tolerância no plano religioso e a protecção dos artistas e da liberdade de expressão. Foi um nacionalista atípico no panorama português do seu tempo, quando por "nacionalismo" se entendia uma mescla de autoritarismo, tradicionalismo e catolicismo." (BARRETO, 2015, p. 189).
} 


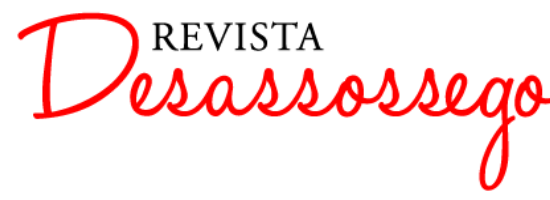

DESASSOSSEGO 20 | DEZ/2018 | ISSN 2175-3180

DOI: http://dx.doi.org/10.11606/issn.2175-3180.v10i20p44-57

impossível pensar que Ricardo Reis, o heterônimo neoclássico, tenha manifestado qualquer tipo de preocupação efectiva com a História e o mundo circundantes” (FRIAS, 2014, p. 80)

Numa leitura mais imediata, é natural ler "Os jogadores de xadrez" como expressão lapidar desse perfil alheado de Reis. Mas também como indício da complexidade que essa postura assume quando transposta para o plano da criação artística por um grande poeta, pois, como nos lembra Alfredo Bosi, o contexto mitopoético da poesia é capaz de rasurar, contrapor e redimir as posições ideológicas de seus autores, reconfigurando-as como gestos de resistência (BOSI, 2010, p. 178).

Neste poema, que se configura, novamente segundo Joana Matos Frias, como uma das composições mais inesquecíveis e mais perturbadoras de Pessoa (FRIAS, 2014, p. 82), temos um texto fortemente narrativo. A introdução do poema é feita com uma fórmula típica das narrativas orais tradicionais (“'Ouvi dizer que outrora...”), o que o inscreve, desde o início, no âmbito da "experiência que passa de pessoa a pessoa [e que] é a fonte a que recorreram todos os narradores" (BENJAMIN, 1996, 198). Incorporando uma estratégia narrativa cara a estes narradores orais, a ação é deslocada para um tempo remoto e impreciso ("outrora", "quando", “não sei qual guerra”), num espaço carregado de exotismo, próprio das fábulas, parábolas e mitos:

Ouvi contar que outrora, quando a Pérsia

Tinha não sei qual guerra, Quando a invasão ardia na Cidade

$\mathrm{E}$ as mulheres gritavam, Dois jogadores de xadrez jogavam

O seu jogo contínuo.

(PESSOA, 2006, p. 30)

Vemos dois jogadores disputarem pacientemente uma partida de xadrez, enquanto ocorria uma "guerra qualquer" na Pérsia. Numa gradação muito bem forjada pelo poeta, a cada estrofe o horror da chacina se aproxima dos estáticos jogadores, num crescendo de violência e tensão. Quanto mais as descrições das mortes tornam-se tórridas e sangrentas, mais perturbador fica o contraste da guerra com a higiene anódina do jogo que prossegue, à deriva no tempo, espacialmente "perto da cidade" mas "longe do seu ruído": 


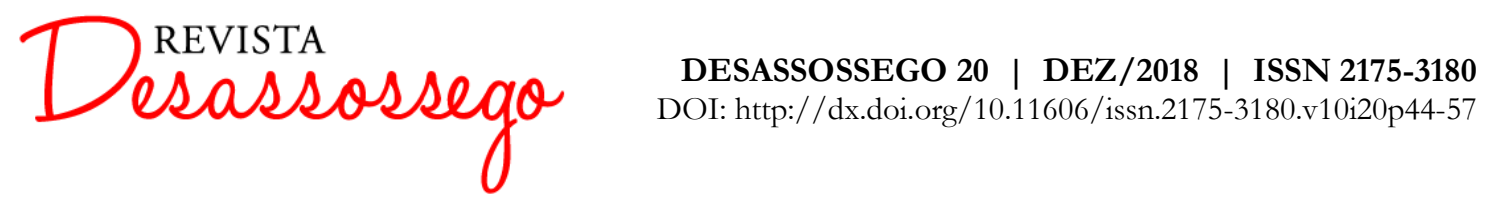

Ardiam casas, saqueadas eram
As arcas e as paredes,
Violadas, as mulheres eram postas
Contra os muros caídos,
Traspassadas de lanças, as crianças
Eram sangue nas ruas...
Mas onde estavam, perto da cidade,
E longe do seu ruído,
Os jogadores de xadrez jogavam
O jogo e xadrez.

(PESSOA, 2006, p. 31)

A partir da sétima estrofe, o tom objetivo da narrativa dá lugar à imaginação e ao julgamento ético por parte da voz poética. Com o verso "Mesmo que, de repente, sobre o muro" passamos do domínio da "realidade" para o da cogitação, espécie de duplo do exercício intelectual dos jogadores. O poema suspende a narrativa, isto é, congela o tempo, às vésperas do encontro mortal entre soldados e jogadores. Penetramos, a partir daí, no domínio da morte não por meio da narrativa direta, mas por construções no modo subjuntivo que convidam a imaginar o momento em que os jogadores seriam enfim brutalmente assassinados, deixando a partida eternamente por terminar. É através desta imagem cogitada que, no restante do poema, dar-se-á o elogio à postura dos jogadores. Quando seria esperável o escândalo e a indignação diante da cena trágica, a voz poética extrai da morte vã dos jogadores uma lição exemplar: os exalta como modelo de conduta, preferindo a suavidade simétrica do tabuleiro à ação caótica dos combates:

Aprendamos na história

Dos calmos jogadores de xadrez

Como passar a vida.

Tudo o que é sério pouco nos importe,

O grave pouco pese,

O natural impulso dos instintos

Que ceda ao inútil gozo

(Sob a sombra tranquila do arvoredo)

De jogar um bom jogo.

(PESSOA, 2006, p. 33) 


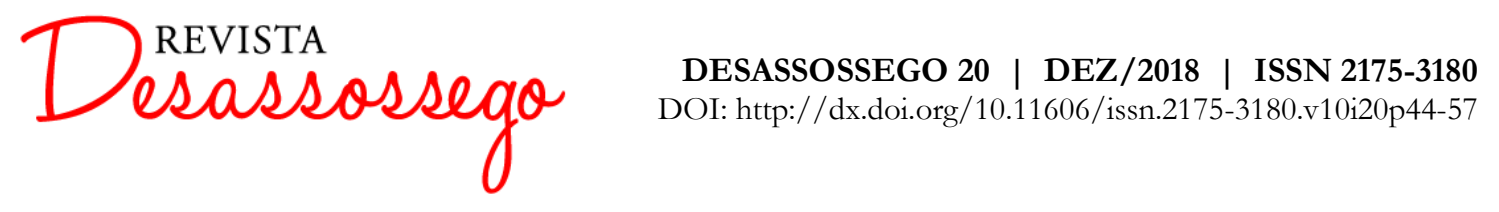

O poema é simultaneamente terrível e singelo. O pendor helenista de Reis ressalta na linguagem sóbria e no ritmo harmonioso dos versos, convivendo contraditoriamente com a vibrante descrição de cenas sangrentas. A indiferença pela guerra surge desde a estrofe de abertura, quando o sujeito se refere, com certo desdém, a "não sei qual guerra", como se o que importasse desde o primeiro momento não fosse a referência concreta à guerra, mas à "moral" que se extrairá dela.

As possibilidades de leitura são inúmeras: Lisa Vasconcellos (2012) opta por uma análise adorniana do poema, demonstrando como a postura de recusa e refúgio que o poema adota em sua superfície revela uma posição axiológica de resistência diante das intempéries da vida política. Maria Helena Garcez (1990), em O tabuleiro antigo, chama atenção para o fato de ser este o primeiro poema escrito por Pessoa após a morte de seu grande amigo Mário de Sá Carneiro, extraindo deste dado biográfico uma interpretação calcada na necessidade de, diante das agruras inevitáveis da vida, se dedicar aos elementos lúdicos da existência, como a poesia, único espaço de realização possível, ainda que sempre imperfeita. Joana Matos Frias (2014) explora as possíveis relações do poema com a I Guerra Mundial, lembrando-nos, por sua vez, que o texto foi escrito no segundo dia da maior batalha naval ocorrida naquela guerra, entre britânicos e alemães. A autora ressalta a necessidade de se evitar o condicionamento determinista da leitura, mas sem esquecer da articulação, nem sempre direta e imediata, que uma obra de arte estabelece com seu tempo histórico, analisando a função do deslocamento proposital para uma temporalidade e um espaço frontalmente oposto ao contexto europeu de então.

A referência ao xadrez constitui evidentemente uma alegoria do próprio fazer poético. O jogo, no caso em questão, demarca os limites da poesia diante da história, evocada aqui como catástrofe. Temos, portanto, o jogo de xadrez como metáfora da poesia e, tão importante quanto, o xadrez, ao longo do poema, é a todo momento emoldurado por uma aura aristocrática, elitista, refinada e desinteressada. Num eixo temos o exercício paciente dos jogadores sobre o tabuleiro: o marfim das peças, a solenidade do rito, o cálculo que guia pacientemente cada movimento das peças. Tudo é limpo, lógico, dominado por uma duração própria, na qual a causalidade das estratégias empreendidas não podem ser medidas pelo tempo humano, somente por uma temporalidade própria que anseia por autonomia em relação aos 


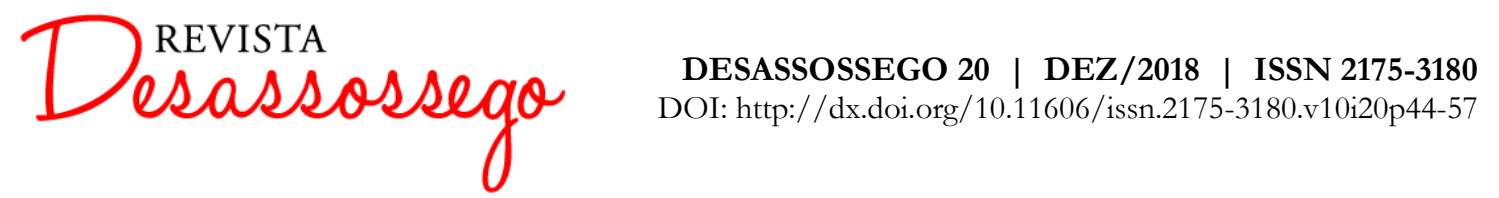

apelos do mundo. O plano dos jogadores é marcado pela passividade contínua: do início ao fim do poema, a postura é a mesma, serena e indiferente. No outro eixo, que ronda os jogadores, o cenário é de agitação. Há movimento, os gritos se tornam mais próximos, mais dilacerados. A introdução do poema, que explora os chavões das lendas, se abre para a tensão entre estes dois espaços que irão fatalmente se cruzar - ainda que no âmbito do pensamento -, sendo aquele (o da placidez do jogo) destinado a ser devorado e neutralizado violentamente pelo segundo (o da fúria da guerra).

Após a menção ao assassinato dos jogadores, a "moral" formulada pelo poema opera no limite da ironia. O elogio hiperbólico dos jogadores chega a um nível que beira a derrisão:

Quando o rei de marfim está em perigo,

Que importa a carne e o osso

Das irmãs e das mães e das crianças?

Quando a torre não cobre

A retirada da rainha branca,

O saque pouco importa.

E quando a mão confiada leva o xeque

Ao rei do adversário,

Pouco pesa na alma que lá longe

Estejam morrendo filhos.

$$
\text { (PESSOA, 2006, p. 71) }
$$

Neste ponto não sabemos mais as bases sobre a qual estão fundadas o cinismo deste contador de histórias. É difícil, conhecendo a obra de Pessoa e, sobretudo a de Ricardo Reis, ler o poema na chave de uma simples ironia retórica. Isto é, ler o elogio dos jogadores inertes, morrendo sem reagir, como se, noutro nível da expressão, essa postura estivesse sendo na verdade censurada pelo poema e demandasse do leitor uma desconfiança diante da apologia feita. Por outro lado, a radicalidade com que o sujeito lírico louva os atos dos jogadores, sem atenuar o impronunciável da guerra, sem eufemismos ou disfarces para suavizar a violência crua dos homicídios, nos leva para um plano de total desestabilização da leitura. É possível tal placidez diante de tanto terror? É desejável tal posição em relação à barbárie?

Sendo o jogo de xadrez uma alegoria do fazer poético, há duas questões centrais colocadas pelo poema e que escapou aos comentadores aqui referenciados. Primeiro, o poema parece insistir, em sua superfície, que o jogo de xadrez corresponde a uma antítese da guerra - 
atividade lúdica, aristocrática, na qual os rivais refinadamente abrem mão da força física -, mas, é preciso lembrar, o xadrez é também, e antes de qualquer outra coisa, uma imitação dos movimentos da guerra. Com suas figuras, embates internos, capturas e ataques, o xadrez é a projeção mimética de uma guerra. A fuga da guerra é feita, portanto, num espaço em que a guerra está presente de outra forma, simulada, mas está lá. Há uma outra guerra ocorrendo na batalha do tabuleiro, uma guerra de inteligência e cavalheirismo, por certo, porém que espelha os movimentos do combate real. "Os jogadores de xadrez" nos fala da guerra real, suja e sangrenta, para negá-la; entretanto, a partida celebrada no poema como ação ideal e pura, e que simboliza o fazer poético em tempos sombrios, é também um prolongamento da guerra, um testemunho.

A catástrofe se acerca do fazer artístico ameaçando sua autonomia, o seu caráter estrategicamente deslocado do real: "Mesmo que o jogo seja apenas sonho/ E não haja parceiro/ imitemos os persas dessa história” (PESSOA, 2006, p. 72). Mas, como vimos, esta evasão repõe, por meio da escolha nada casual pelo xadrez, o tema da guerra. É como se coubesse à poesia, afugentada pela barbárie, contornar a literalidade da catástrofe, não para negá-la simplesmente, mas para reencontrá-la num outro nível, mais humano.

Ademais, cabe frisar que o xadrez só pode ser efetivamente jogado quando há dois competidores. A partida pode até ocorrer na solidão do sonho, como nos diz o poema, mas há sempre um outro jogador-leitor, ainda que virtual, com o qual a expressão do horror se debate para existir. Portanto, nesta arte poética às avessas, a poesia é louvada como alternativa para se manter uma dignidade diante da inumanidade dos combates. Porém, não é a jardins floridos ou a templos remotos e aprazíveis que o poeta recorre para simbolizar o seu anseio de escape, é a um jogo que existe enquanto duplo da guerra e que é jogado arriscadamente bem ao lado do labor dos conflitos. O jogo é uma representação, num plano elevado e fatalmente inconcluso, da poesia que se consuma como testemunho do horror. Por isso a previsível e esperada morte violenta dos dois jogadores deixaria a partida por terminar, como é próprio de toda escrita que se acerca da catástrofe.

\section{$O$ arquiteto entre as pedras}




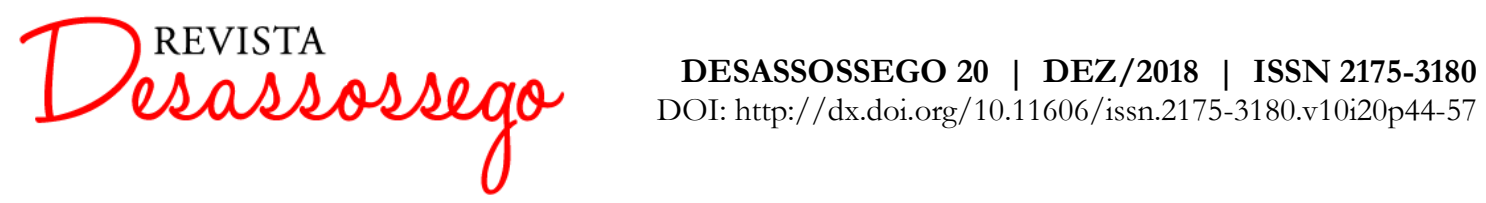

\section{Lição do arquitecto Manuel da Maia}

Durante dois anos removeu as pedras incansavelmente vasculhou as ruínas durante dois anos depois do terramoto. Ele sabia que ali sob a torre caída em cada palavra de cada manuscrito estava a nossa perdida perdida memória. E durante dois anos incansavelmente procurou nas ruínas removeu as pedras.

Tu que dizes de tia a parte mais visível não esqueças a lição de Manuel da Maia o arquitecto que reconstruiu a História. Algures dentro de nós há uma torre caída algures na perdida perdida memória. Procura aí a crônica e o poema nessa Torre do Tombo destruída não apenas arquivos papéis pergaminhos procura o sangue do teu sangue o nome do teu nome procura a História já sem vida e a vida feita de História procura o tempo e seu sentido sob a torre caída da nossa perdida perdida memória.

(ALEGRE, 2009, p. 304)

"Lição do arquitecto Manuel da Maia" é o poema de abertura de Atlântico, livro publicado por Manuel Alegre em 1981, obra que opera na trajetória do autor como ponto de transição entre o canto participante, coletivo e de intervenção - que predomina em seus primeiros livros - e o balanço crítico, desencantado e melancólico presente na obra seguinte, Babilônia (1983). Trata-se de um poema destacado no livro pelo uso de itálico e anterior à parte I da obra, intitulada "Decassílabos". Por conta dessa posição, o poema assume um caráter de prefácio lírico e arte poética, oferecendo pistas de leitura e antecipando o tema central do livro: o embate entre a História portuguesa, com seus mitos, obsessões e fraturas, e o trabalho poético de reconstituição do passado por meio do trabalho ativo com a memória. A tensão e correlação entre memória e História estão no cerne do poema em estudo e do livro Atlântico, sendo, além disso, uma marca do projeto artístico de Manuel Alegre. Eduardo Lourenço o define como "poeta-mitólogo por excelência", sendo este interesse pela ressignificação dos mitos nacionais uma marca de seu incessante trabalho com a "memória portuguesa, alimento 


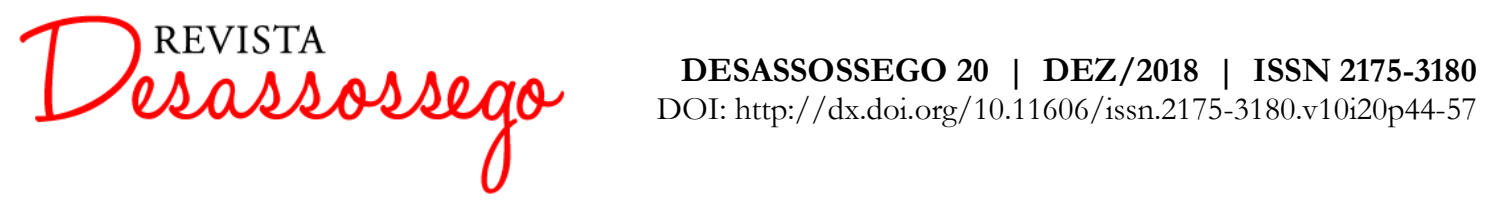

primeiro de seu imaginário, não como mera fonte de inspiração ou mimese formal [...] mas como ideário, como fábula, como epopeia” (LOURENÇO, 1995 apud ALEGRE, 2009, p. 858).

O poema supracitado busca a sua lição não numa lenda antiga e distante, como vimos em Ricardo Reis, e sim em um dado histórico que assume dimensão simbólica e mítica: o trabalho do engenheiro e arquiteto Manuel da Maia, guarda-mor da Torre do Tombo durante o terremoto que devastou Lisboa em 1755. Já com idade bastante avançada, na casa dos 70 anos, Maia enfrentou as chamas que ameaçavam os documentos históricos sob sua responsabilidade. Conseguiu salvar um volume monumental de obras e, nos anos seguintes, se dedicou a vasculhar os escombros em busca de material perdido. O poema explora a ironia de o arquiteto, um construtor por profissão, ter que lidar com as ruínas, com a destruição, causada pela mesma natureza que ele, por ofício, busca domar pelo interesse humano.

O horizonte de combate político que a poesia de Alegre assume como tarefa primordial se revela, principalmente, pelo amplo processo de desvelamento da história portuguesa empreendido em sua poética. Luta-se, sobretudo, contra os mitos paralisantes, anacrônicos e opressivos alimentados pela ideologia salazarista que fixou, até a exaustão, uma "história oficial” e uma mitologia nacional coerentes com os desígnios autoritários do regime. Assim, na obra de Manuel Alegre "a História é tema e discurso, é texto e contexto, é ela que o poeta interroga e por ela que canta, em suma, é a História o seu grande manancial poético" (LUGARINHO, 2005, p. 74). Entenda-se desde já que a centralidade da História não significa emulação da objetividade do discurso historiográfico, ou mesmo uma filiação irrestrita a ele. Ao contrário, o embate com a história frequentemente nos revela um trabalho de demolição dos dogmas que alicerçaram o pensamento histórico em Portugal na busca de uma saída política que, no labor de conjugar poesia e memória, restabeleça os sentidos coletivos constantemente ameaçados pelo enrijecimento da história do país por conta dos mitos colonialistas.

Trata-se, em suma, de enfrentar a História para libertá-la - inclusive a história literária, também aliciada pela história oficial. Daí seus insistentes diálogos com Camões e outros poetas e pensadores portugueses e clássicos, gerando um turbilhão de intertextos que revigoram, a 


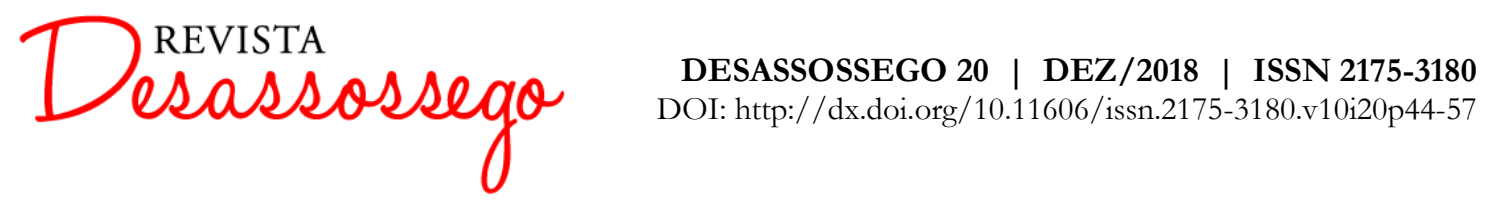

contrapelo, o lugar desestabilizador (e não mais agregador ou conciliador) da tradição literária lusitana.

Voltando ao poema "Lição do arquitecto Manuel da Maia”, vemos que essa perspectiva é formulada a partir do elogio do trabalho arqueológico realizado por Maia após o terremoto. A catástrofe com a qual o poema se debate não é a da guerra, mas a da tragédia natural e seus efeitos igualmente destrutivos. O trabalho físico e manual de "remover pedras" e "procurar nas ruínas" é também uma clara metáfora do fazer literário. Ou seja, também temos, na parábola montada por Alegre neste poema, uma espécie de arte poética do livro a que serve de abertura - e, por que não, de toda a poética alegriana. Se em Ricardo Reis o que salta aos olhos é a valorização de uma distância estratégica em relação à tragédia - num hiperdimensionamento da vivência estética e lúdica dos jogadores, em oposição aos imperativos éticos que marcam a catástrofe - em Alegre é no meticuloso exercício de tocar a ruína, com paciência e discernimento, que o poema encontra sua expressão mais adequada. As mãos limpas dos jogadores imersos no tabuleiro se opõem às mãos sujas do arquiteto solitário que revira a "perdida perdida memória".

Nos escombros da torre caída está a memória portuguesa, simbolicamente ativada na crise ideológica que assinala o presente do poema, num momento de redemocratização e de turbulências e frustrações vividas após a Revolução dos Cravos. Naquelas ruínas da torre está a memória de Portugal e nela o sangue e os nomes necessários para se conceber um projeto de país, uma reconstrução. O fazer poético é análogo ao trabalho de escavação empreendido por Manuel da Maia, sendo que Alegre encontra nessa imagem uma vívida alegoria de seu projeto literário, formulado como "autêntico exercício de arqueologia" (LOURENÇO, 1995 apud ALEGRE, 2009, p. 858). A História ali é “já sem vida”, mas, paradoxalmente, é "vida feita História".

Num livro que revisita insistentemente as tradições portuguesas, no intuito de questionar seu lugar no presente e as possibilidades de futuro que podem ser extraídas desse arcabouço mítico-cultural, Manuel da Maia surge como arquétipo do poeta-historiador do presente. Seu estatuto se aproxima do trabalho histórico benjaminiano, ao lidar com as pedras (símbolo do peso bruto que esmaga a fragilidade da memória) no caminho da recordação. Contra o esquecimento, que abortaria o projeto de reconstrução a partir das ruínas, faz-se 


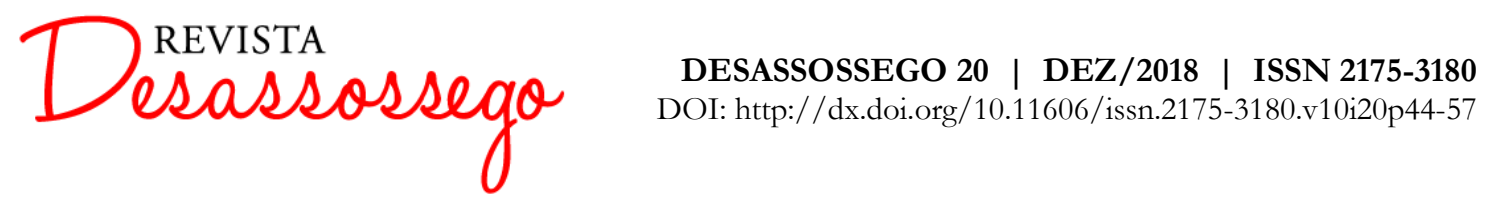

necessário um ativo trabalho que envolve paciência, como indica a repetição do período "dois anos" e do advérbio que enfatiza o vagar da tarefa, "incansavelmente". A poesia coloca-se assim como o exigente burilar das lacunas e contradições que o discurso da História oficial encortina. O meio para desvelar esses silêncios passa pela ativação de uma memória coletiva, revigorada pelo sentido vivo e questionador da arte. Se o arquiteto revira as pedras em busca de um patrimônio imaterial, incalculável, tragado pelos escombros, o poeta precisa, por sua vez, revirar a torre tombada que há "Algures dentro de nós". Assim, a vocação épica do poeta que explora a experiência legada pelo passado português se conjuga no sentido lírico da subjetividade em crise, trazendo para o drama político do presente o sentido mnemônico, por isso inconcluso, dessa reconstituição.

\section{Algumas conclusões}

Observamos nos dois poemas analisados uma marcante semelhança estrutural, apesar da considerável diferença de extensão entre eles. Ambos se organizam a partir de uma alegoria do fazer poético estabelecida por meio de uma narrativa exemplar, que mescla traços da parábola e do gênero epidítico. Nota-se neles dois momentos distintos, muito bem demarcados no fluxo textual: o da apresentação de uma história (uma lenda clássica em Reis e um fato histórico-mítico em Alegre) e, na sequência, o elogio dos modelos representados nas narrativas e a formulação de uma "lição" a partir delas.

Indo além dessa construção comum, observamos que em cada um se constrói um modo particular e, à primeira vista, antagônico de se pensar a relação entre poesia, história e catástrofe. A postura exaltada em "Os jogadores de xadrez" é a da indiferença, do alheamento, do recuo estratégico à torre de marfim como alternativa ao enfrentamento das mazelas da guerra. Em Manuel Alegre, por sua vez, o exemplo de Manuel da Maia é celebrado como postura ativa diante da catástrofe: o revirar de pedras e escombros, ou seja, o transitar entre ruínas, constitui-se ali como arte poética em sua tarefa infinita de escavar os mitos que falseiam a História portuguesa e extrair dela a memória do horror como meio de resistir às contradições do presente, seja os tempos sombrios do salazarismo, seja, mais adiante, os percalços da integração portuguesa à Europa em tempos de hegemonia neoliberal. 


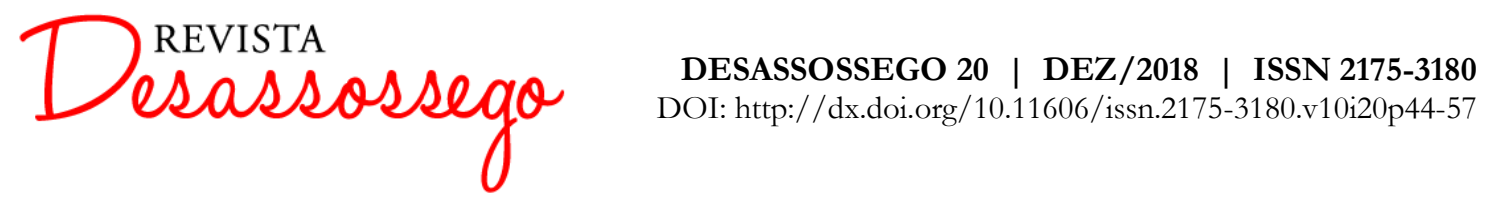

Não é lícito atenuar, no cotejo dos dois poemas, a distância entre as implicações políticas que neles se manifestam ou, menos ainda, relativizar a postura evasiva da poética de Reis para aproximá-la da postura abertamente engajada da obra de Manuel Alegre. Essa distância existe e reverbera modos distintos de encarar a história do século XX. Contudo, podemos concluir afirmando que estes dois polos, sobretudo quando canalizamos nossa reflexão para as relações entre poesia e história, não são totalmente irreconciliáveis. Ao contrário, eles pulsam dentro de um mesmo dilema, de um mesmo campo fértil de interrogações.

No poema de Ricardo Reis, o recurso à imagem estática e altamente plástica dos dois parceiros jogando xadrez representa não somente o exercício lúdico e o prazer do esquecimento de si, diante da inutilidade da ação, mas também o deslocamento do mundo bélico para a mimese do xadrez. Os jogadores anestesiados pelo jogo, no afã de ignorar os chamados de uma ordem social em derrocada, vão ao encontro de uma projeção outra da guerra, mais racional, limpa, sofisticada. Mas, ainda sim, da guerra.

Como poema que enaltece o desdém pela guerra é, a sua maneira, um poema de guerra; um poema que expõe a transitividade da poesia e a fragilidade dela em relação aos bárbaros que batem à porta. É neste sentido que o impasse entre poesia, história e catástrofe se articula em dois poemas ao mesmo tempo tão parecidos e tão diferentes. A ataraxia dos enxadristas, em sua eternamente inconclusa partida, mortos e salvos pelo poema, se atualiza, às avessas, no paciente vasculhar de ruínas em "Lição do arquitecto Manuel da Maia". A ruína e o torpor se comprazem na paciência necessária para reescrever, ou rasurar, poeticamente a história e historicamente a poesia.

\section{Referências}

ALEGRE, Manuel. Poesia. Vol. I e II. Lisboa: Dom Quixote, 2009.

BARRETO, José. A poesia política de Fernando Pessoa. Revista do Núcleo de Literatura Portuguesa e Africana da UFF. Vol. 7, no 14, $1^{\circ}$ sem. 2015. 


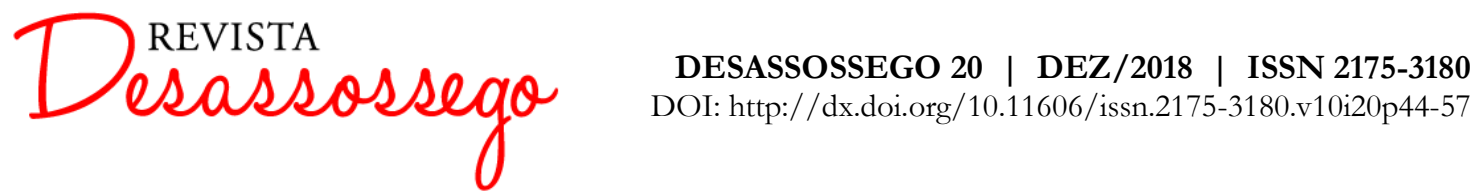

BENJAMIN, Walter. Magia e Técnica, Arte e Política. Trad. Sergio Paulo Rouanet. São Paulo: Brasiliense, 1996.

BOSI, Alfredo. O Ser e o Tempo da poesia. São Paulo: Cia. das Letra, 2010.

HOBSBAWM, Eric. A Era dos extremos: o breve século XX (1914-1991). Trad. Marcos Santarrita. São Paulo: Cia. das Letras, 2010.

FRIAS, Joana Matos. A guerra em Pessoa. Cadernos de Literatura Comparada - Instituto Margarida Losa. No 31, dez. 2014, pp. 79-106, Porto.

LUGARINHO, Mário César. Manuel Alegre: mito, memória e utopia. Lisboa: Colibri, 2005.

PESSOA, Fernando. Poesia de Ricardo Reis. São Paulo: Martin Claret, 2006.

SALGADO, Maria Teresa; ATHAYDE, Rogério. A vida em preto e branco: leitura possível de "Os jogadores de xadrez" de Ricardo Reis. Revista Contraponto, Belo Horizonte. Vol. 3, n 4, 2013. PP. 73-86.

SARAMAGO, José. O ano da morte de Ricardo Reis. Lisboa: Caminho, 1984.

VASCONCELOS, Lisa. Ricardo Reis: poeta engajado?. Revista Literatura e Autoritarismo - Santa Maria. Dossiê no 12, nov. 2012, pp. 110-120. 